\title{
ACRL preconferences in Chicago
}

\section{The topics will be documenting cultures and legal research}

$\mathbf{A}$ CRL will offer two preconferences prior to the ALA Annual Conference in Chicago this summer. Details about both follow. Brochures for both preconferences are available from the ACRL office. To request one of the brochures call the ACRL office at (800) 5452433 , ext. 2510 or 3248 ; fax your request to (312) $280-2520$; or send e-mail to: althea. jenkins@ala.org.

\section{6th rare books preconference}

"Collecting Cultures: The Politics and Practice of Building Special Collections" is the theme of the Thirty-Sixth Preconference of the Rare Books and Manuscripts Section of ACRL, to be held at Indiana University, Bloomington, from June 20-23, 1995.

The plenary sessions and seminars will focus on the role of special collections in documenting cultures. Drawing on current trends in scholarship, participants will explore how modes of collecting both reflect and influence modes of scholarship. The preconference will rigorously examine the constructs that inform the traditional ways special collections have been built and will evaluate those constructs in the light of contemporary scholarship in the humanities and social sciences.

The program will bring special collections librarians together with a variety of scholars who use primary sources in new ways; it will introduce the array of new scholarly paradigms that are being used, query the constructed nature of special collections, and explore both librarians' and scholars' understanding of the role libraries play in providing primary research materials and preserving culture in its broadest terms. Throughout the preconference, emphasis will be placed on integrating theoretical approaches taken from scholarship with practical applications by special collections librarians in their day-to-day work.

A variety of professional development seminars will be provided; in addition, a special, day-long limited enrollment workshop on rare book reference sources will be offered.

Speakers. Carolyn Dever, New York University: "Taxonomies of Gender: Sex, Authorship, and the Archaeology of Research in Victorian Studies"; Mark Dimunation, Cornell University, Ithaca, New York: "Past Reconsiderations: Re-reading Our Collections through the Lens of the New History"; John Durbam, Bolerium Books: "Collections, Cultures: A Bookseller's View"; Eugene Eoyang, Indiana University, Bloomington: Informal remarks about his book Coat of Many Colors from a Minority of One (Beacon Press, 1995); Frances Smith Foster, Emory University: "ReCollecting Texts, ReConsidering Contexts"; Henry Glassie, Indiana University, Bloomington: "Libraries, Museums, and Cultures"; Holly Hall, Washington University, St. Louis: "Subjectivity As Everybody's Subject: Some Object Lessons for Literature Collections"; Elisabeth Kennedy, State University of New York at Buffalo: "The Importance of Oral Histories in Documenting Working-Class Lesbian Culture"; Teresa Mangum, Iowa State University: "Finding the History of Aging in the Nineteenth Century"; Cathy M'Closky, York University, Canada: "Marketing Multiple Myths: The Hidden History of Navaho Weaving As Revealed in the Lorenzo Hubbell Papers"; Simon Mongan-Russell, Bowling Green State University: "A Renaissance of Queer Materials: Rethinking the Evidence"; Cary Nelson, University of Illinois, Urbana-Champaign: "The New Archaeological Library: Preserving Material Culture, or, Why Does the Library Need an Old Pair of Shoes?"; David Nord, Indiana University, Bloomington: "There's More to a Newspaper Than the Newspaper: Doing Journalism History in Manuscript Collections"; Brad Westbrook, University of California, San Diego: "Lighting Up the Territory." 
Seminars. Opportunities for continuing education and professional development will include a variety of seminars for preconference participants. Topics include: a scholar's forum on new uses of special collections materials; locating literary manuscripts; dealing with duplicates; cultural and ethnic special collections; provenance and rare materials cataloging; cataloging rare serials; collecting children's literature; mentoring in special collections librarianship; perspectives on teaching the history of the book; working with guest curators for exhibitions; Renaissance bibliography; digital image access projects; cooperative collection development; planning for new buildings; and security issues facing special collections.

Tours. Kinsey Institute for Research in Sex, Gencler, and Reproduction; Archives of Traditional Music; Literary Electronic Text Resource Service (LETRS); Music Library and Variations Project; Musical Arts Center.

Tours of libraries and special facilities on the Indiana University Campus will be offered concurrently with the seminars. Space will be limited. Sign-up for the tours will be at the registration desk at the Indiana Memorial Union Conference Lobby, Mezzanine Level.

Registration. Registration is limited to the first 250 applicants. The registration fee of $\$ 175$ for ACRL members, or $\$ 210$ for non-ACRL members, must be included with the registration form. This fee includes: entry to all preconference receptions, luncheons, and coffee breaks; and entrance to all preconference papers and seminars. A special student registration fee of $\$ 75$ is available for all currently enrolled, fulltime students. This fee includes entry to all preconference papers, seminars, receptions, and breaks, but not lunches. A separate fee of $\$ 35$ will be charged for the optional trip to Nashville, Indiana, on Thursday evening. To register for this RBMS preconference contact the ACRL office at (800) 545-2433, ext. 2510 or 3248.

Housing and transportation. Housing is available on the Incliana University campus in Eigenmann Graduate Residence Center, which offers single, air-conditioned rooms with samesex floors and community bathrooms. Each room has a phone and data jack. Linens are provided. The cost will be $\$ 28.50$ per night.

Most travelers fly into the Indianapolis International Airport and connect to Bloomington with ground transportation.

Details on alternative housing and transportation information are given in the precon- ference brochure. You may request one from the ACRL office by calling ( 800 ) 545-2433, ext. 2510 or 3248 .

\section{Legal research for non-law librarians}

"Taking the Mystery out of Legal Research for Non-Law Librarians" is the preconference being offered by ACRL's Law and Political Science Section (LPSS), 8:30 a.m.-5:00 p.m. on Friday, June 23. Lunch will be included.

This full-day conference is for librarians who want to learn more about legal reference and how to assist their patrons in doing legal research. Librarians who are experienced in doing legal research will provide an introduction to the legal system in the United States. Participants will learn how laws get passed and where to locate the texts of laws, both federal and state. They will learn the basics of finding administrative regulations and court reports. The preconference will conclude with a panel discussion on applied legal reference. A major electronic publisher will demonstrate its online reference system. The program will be followed by a vendor fair with representatives from both print and electronic publishing.

Audience. Academic librarians and public librarians needing an introduction to or review of legal reference. The program will bring them up-to-date with new sources of information.

Speakers. Lorraine Kulpa, Baker and McKenzie Library: "Introduction to Legal Research"; Natalie Schatz, Fletcher School of Law and Diplomacy Library: "Legislative ProcessStatutes and Codes"; Deanna Wood, University of New Hampshire Library: "Administrative Regulations"; Jacqueline Orlando, Capital University Law Library: "Case Law Research-Reporter System, Digests, How to Shepardize"; Darcy Kirk, Georgetown University Law Library: "Secondary Legal Materials"; Cheryl Nyberg, University of Illinois Law Library: "Looseleaf Services." A panel discussion will be presented by Bnice Kennedy, University of Toledo; Laura Bartolo, Kent State University Library; and Barbara Morgan, University of Massachusetts: "Answering Difficult Legal Questions at the Reference Desk and Library Instruction Programs."

Registration. The registration fee is $\$ 120$ for ACRL members, $\$ 155$ for ALA members, and $\$ 215$ for non-ALA members. The deadline for registration is May 15, 1995. To register for this LPSS preconference contact the ACRL office at (800) $545-2433$, ext. 2510 or 3248 ; fax: (312) 280-2520. 


\section{The State \\ of the Art}

Leaders in the Information

...working

smart

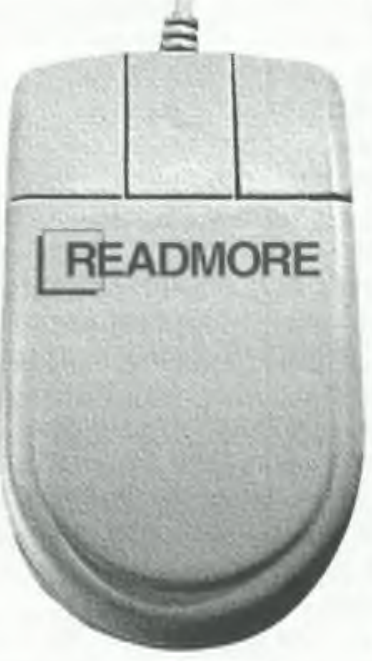

Industry providing subseription services, article delivery and library automation software.

- REMo Mouse driven serials management system.

- Ross Online ordering, claiming and searching of journal and publisher databases.

- Renewal Express PC-based system to analyze current serials holdings and plan for the future collection development.

- Financial Planner Lotus formatted worksheet to analyze previous spending history and plan future budget allocations.

- UnCover The fastest most comprehensive service for fax delivery of journal articles available today.

- Backserv An Internet list devoted to the informal exchange of serial back issues among libraries.

\section{Readmore Academic SeRVICES}

700 Black Horse Pike, Suite 207

Blackwood, NJ 08012

Phone: 1-800-645-6595

Fax: 609-227-8322 